\title{
MUSYKILÂT AT-TA'RîB FÎ TATHAWURI AL-LUGHAH AL-ARABIYYAH
}

\author{
A. Syagif Hanany, M. Pd \\ 4gyptik@gmail.com
}

(Dosen Sekolah Tinggi Ilmu Tarbiyah Sunan Giri Kota Bima)

\begin{abstract}
الملخصص
إن اللغة العربية لغة عالمياة ودينية ذات خصائص متميزة. وكالمظاهر الإنسانية والإجتمائية، كانت اللغة العربية تتأثر في تطورها وإرتقائها بعوامل كثيرة. أولها انتقال اللغة من السلف إلى الخلف. وثانها تأثر اللغة بلغة أخرى. وثالثها التنمية الإجتماعية. ورابعها عوامل أدبية. ومن المعروف أن كلما تقدمت الحضيارة كثرت أشياء جديدة تحتاج إلى تسميات، ولا سيما المصطلحات العلمية. و كان أصحاب اللغة قادرين على تحويل بعض الكلمات المستخدماة في لغة جيرانهم إلى الصيغ والقوانين اللغوية العربية وسميت بالألفاظ المعربة . يعتبر التعريب في دراسـة فقه اللغة أحد طرق فعالة في وضع المفردات الجديدة في اللغة العربية وخاصية في المصطلحات العلمية. فلا عجب أن التعريب له مكانة ضرورية في تطور اللغة العربية من وقت إلى آخر ولا سيما في العصر العولمة. هذه الطريقة أكثر فعالة وأدق دلالة في تأليف المصطلحات الجديدة مع أن تقدم العلوم والأفكار الحديثة مستمرة. بالرغم من ذلك، هناك من يذهب إلى أن وجود التعريب تؤدي إلى المشكلات في اللغة العربية وتطورها. وهي المشكلات في المصطلحات العلمياة و مشكلات الفكر لأصحاب اللغة والمشكلات في التعليم المدرسي.
\end{abstract}

\section{كلمات المفتاح : التعربب، اللغة العربية}

Bahasa Arab telah menjadi bahasa internasional sekaligus menjadi bahasa agama dengan ciri khasnya yang tidak dimiliki bahasa-bahasa lain. Sebagai salah satu entitas antropologis dan sosial, bahasa Arab sebagaimana bahasa lainnya juga mengalami perkembangan karena berbagai macam faktor, diantaranya faktor historis, pengaruh bahasa asing lain, dinamika sosial kemasyarakatan, serta perkembangan kesusastraan Arab. Dan menjadi sebuah keniscayaan, dengan berkembanganya peradaban manusia, semakin bertambah pula hal-hal baru yang muncul dan membutuhkan nama atau istilah untuk menyebutnya dan mendefinisikannya, terlebih lagi pada istilah-istilah ilmiah. Dalam prakteknya, orang Arab memiliki metode tersendiri untuk menyerap kata-kata dari luar bahasanya untuk menjadi kosa 
kata atau istilah bahasa arab setelah melalui proses adaptasi dengan karakteristik dan kaidah linguistik Arab (kalimah mu'arrabah). Proses inilah yang dikenal dengan istilah ta'rib yang dalam kajian Fiqh al Lughah merupakan teknik yang sangat efektif untuk memunculkan leksikon dan istilah baru dalam Bahasa Arab. Karena itu, tidaklah mengherankan jika ta'rib memiliki urgensi yang sangat tinggi dan tidak bisa dihindari dalam perkembangan bahasa Arab dari masa ke masa, khususnya di era globalisasi saat ini.

Di tengah laju perkembangan iptek yang tak terbendung saai ini, $t a$ 'rib dinilai sebagai yang paling efektif secara metodik dan paling akurat secara semantik dalam merformulasikan berbagai kosakata bahasa Arab Baru. Namun demikian, eksistensi ta'rib dan kalimah mu'arrabah ternyata memunculkan berbagai problematika yang berdampak pada perkembangan bahasa Arab, diantaranya adalah problematika penyebutan dan penulisan istilah ilmiah, problematikan paradigma berpikir pengguna Bahasa Arab, dan problematika dalam pengajaran formal.

\section{Kata Kunci: Arabisasi, Bahasa Arab}




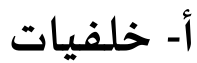

إن اللغـة العربيـة إحـدي اللغـات الســاميـة، وهي لغـة أمـة العرب قـديمـة العهـد

وشــائعة الذكر التى كانت تســكن الجزيرة المنســـوبة علهها من الطرف الجنوبي العربي من

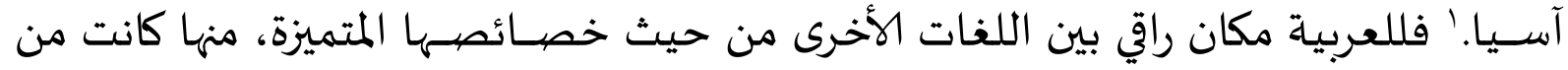

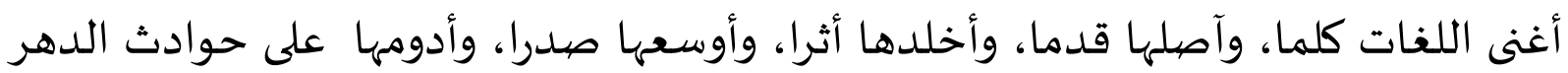

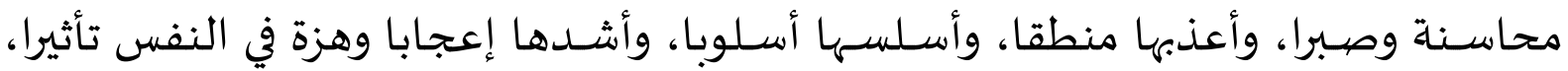

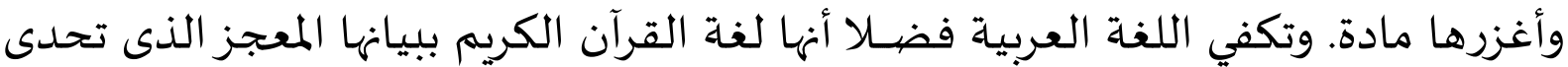

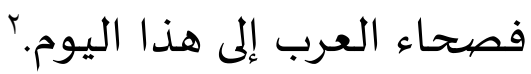

ومهما ميزت اللغة العربية بهذه الفضيلة، فإنها ليست بدعا من اللغات الإنسـانية.

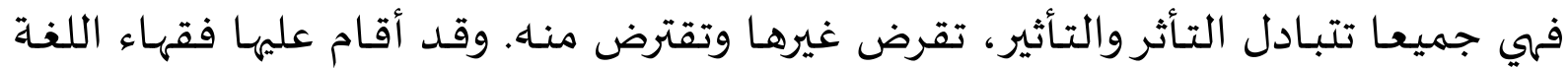

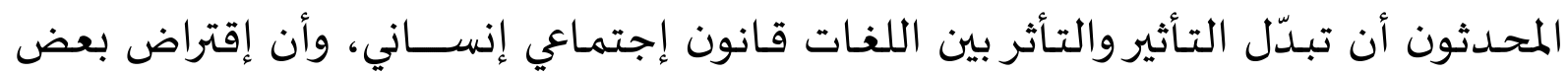

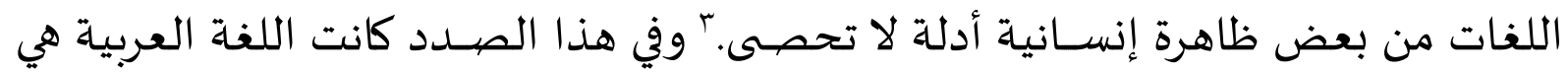

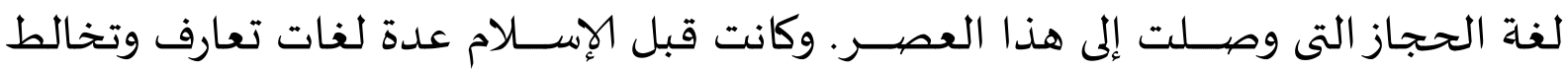
بلغات القبائل. وبينها إختلاف في اللفظ والتركيب. وحينما اختلط العرب بغيرهم من الأمم، كان أصحاب اللغة قادرين على تحويل بعض الكلمات المستخدمة في لغة جيرانهم إلى الصيغ

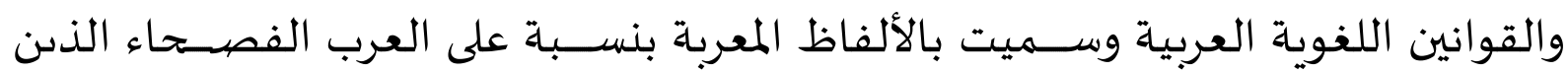
استخدموها على ألسنتهم وأدخلوها إلى لغتهم. واسـتمرت هذه العملية الطبيعية حتى اتسـعت الفتوحات الإسـلامية بعد عصيـر الراشدين والأموي والعباسية وهذه تؤدي إلى دخول كثير من أهل البلاد المفتوحة إلى الإسلام

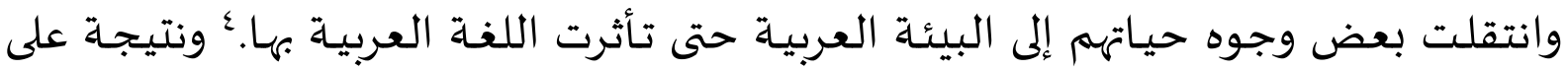

' أحمد الإسكندري ومصطفي عناني، الوسيط في الأدب العربي وتاريخه (قاهرة : دار المعارف العصر،, ط: 11) مجهول السنة،

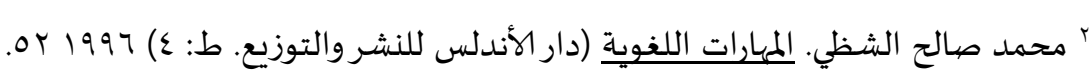

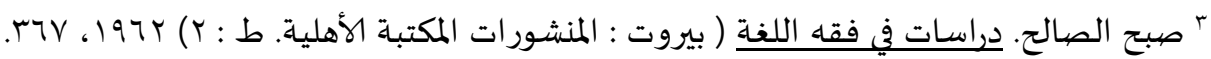

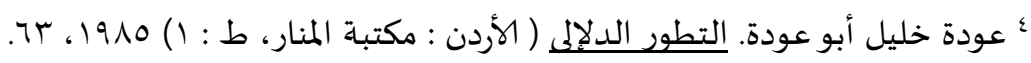


ذلك كثرت في لغـة الأدب والفنون العلمياة ولغـة التخاطب الإجتماعي مأخوذة من الألفاظ

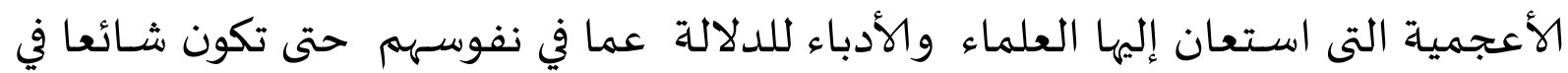

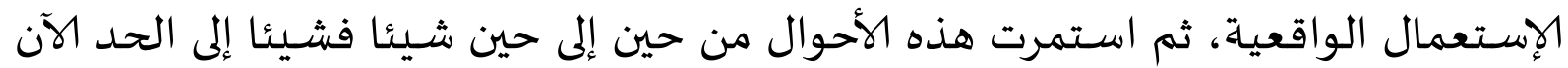

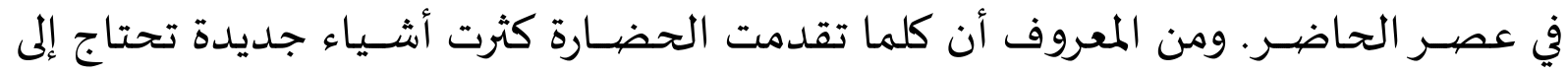

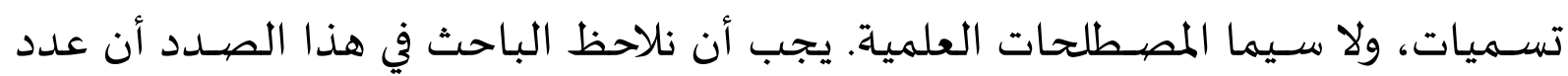

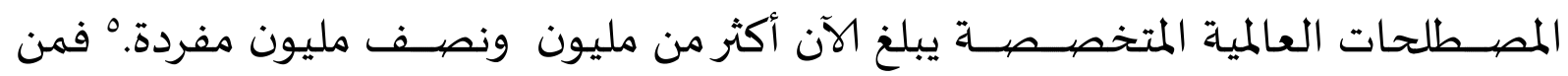
المؤكد أن التعريب إذن، لا مفر منها.

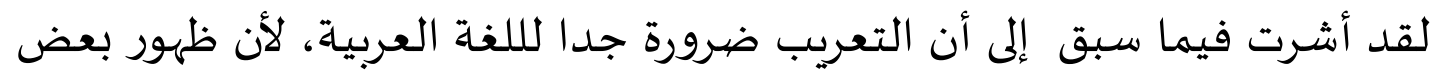

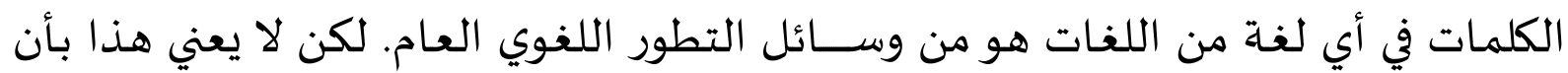

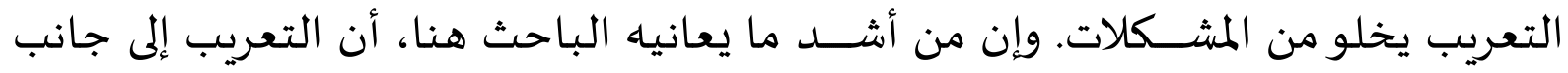

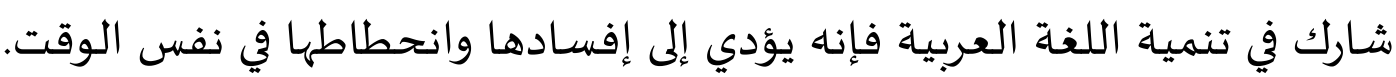
ب. مفهمم اللغة العربية

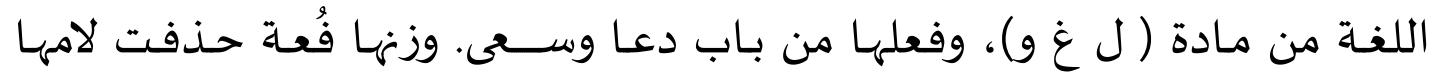

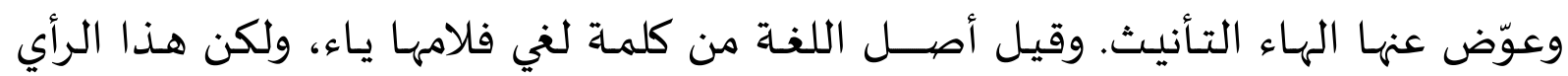

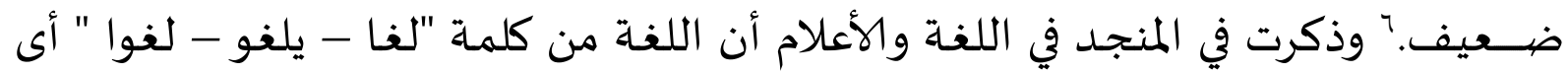

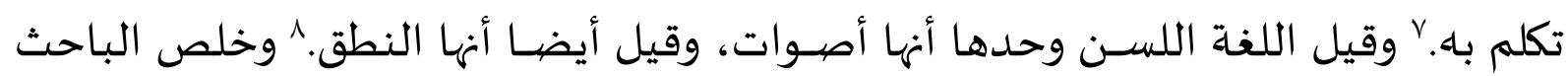

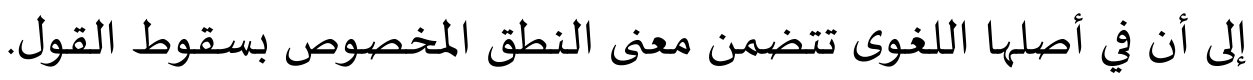

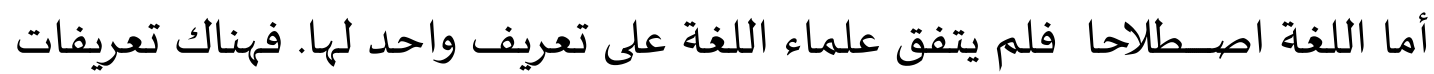

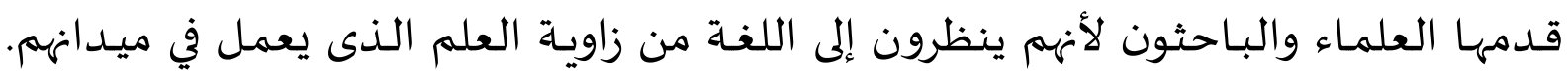

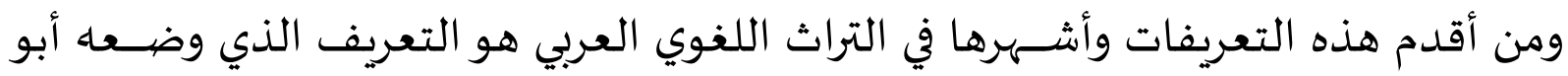

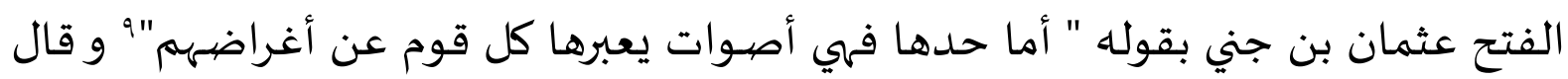

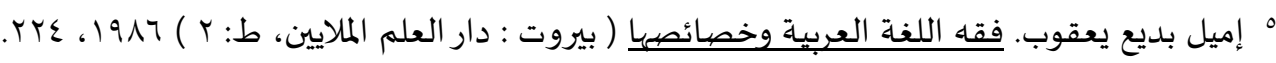

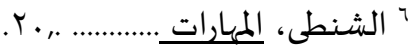

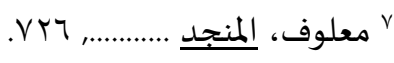

$$
\begin{aligned}
& \text { ^ الشنطى، المهارات ............. }
\end{aligned}
$$

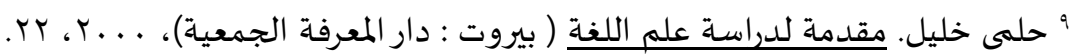


إيراهيم أنيس أن اللغة نظام عرفي لرموز صــوتية يســعملها الناس في الإتصــال بعضـهم بعضـا.' و هناك مفهوم للغة كما قال عالم اللغة الأمريكي إدوارد سـابير (Edward Sapir) "اللغة ظاهرة إنسـانية غير غريزية لتوصيل العواطف والأفكاروالرعبات بواسـطة نظام من

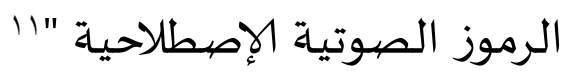
وأما العربية هي نسـبـة من العرب. وهم الذين كانوا يســكنون الجزيرة العربية في الطرف الجنوبي الغربي من آســيا وينطقون باللغة العربية سـليقة وطبعا.ب اللغة العربية إذن هي آلة الإتصال المنطوقة بين القوم في الجزيرة العربية للتعبير والتوصيل أغراضهه.

\section{ج. تطور اللغة العربية} وقد ذكر الباحث فيما ســق أن اللغة العربية من احدى اللغات الســامية، وأطلق مصــطلح السـامية (Semitic) في نهاية القرن الثامن عشــر لدى العلماء الأروبيين، وذلك لأن الشـعوب التى كانت تتكلم اللغات السـامية غالبا ضـمن ذرية سـام بن نوح (وهو في العبرية شـام sem ) وكانت اللغة العربية هي من القسـم الجنوبي من اللغات السـامية.ءُ وإذ أنها من اللغات السامية فمن الطبيعي أن تناسب بعض خصيائص بينهما. حسبما ذكرفي الكتاب تاريخ الإسلامي للدكتور حسن إبراهيم حسن في بحث لفظ "عرب" فيظهر أن المعني الحقيقي للفظ عرب هو صـسخراء. افلا عجب إذا كان أكثر جزء في الجزيرة العربية صـخرائها في وسـطها. وليسـت طبيعة هذه الصسخراء متشـابهاة، بل متفرقة على ثلاثة أنواع : أولها الصـسخراء الســماوة في الشــمال، وثانها الصــخراء الجنوب، وثالثها الصسخراء الحرات في الشـرقى." ويقسـم جغرافيو العرب الجزيرة العربية من حيث طبيعتها

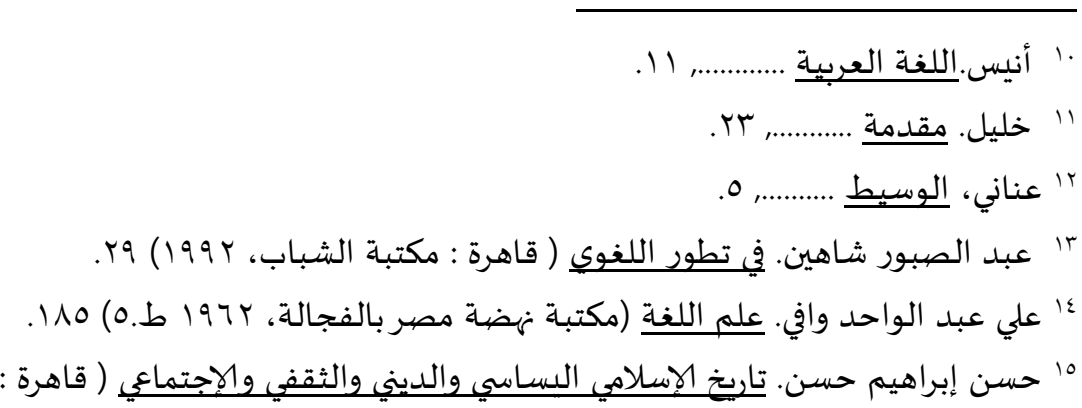

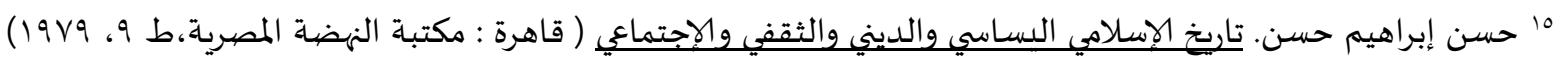

17 أحمد أمين. فجر الإسلام ( قاهرة : مكتبة الهضية المصرية،ط 113 19v0) 1 ا. 


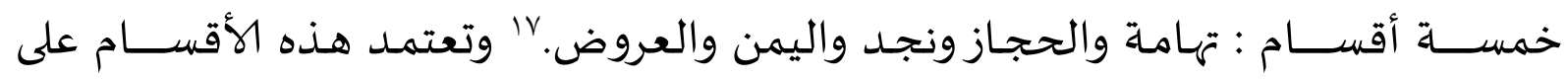
الطبيعة الجغرافية كموضع وإقليم ودراجة الحرارة ونصب.

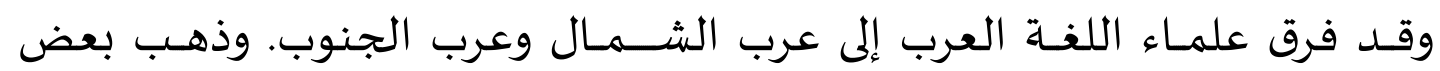

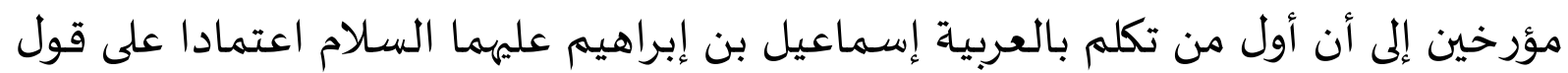

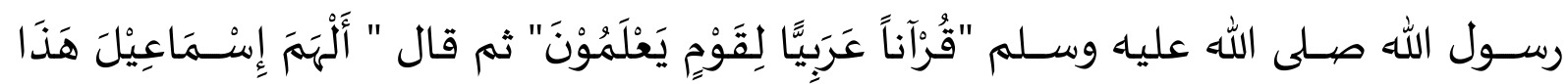

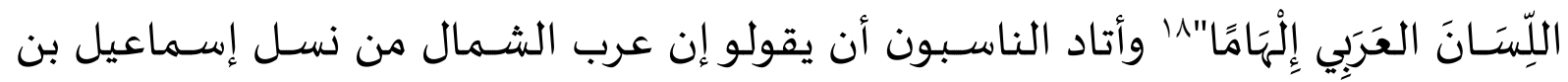
إبراهيم عليهما السلام وعرب الجنوب من نسل يقطان المسمى أيضا قحطان، ثم يسمى أهل الشــمال العدنانيين وأهل الجنوب القحطانيين.19 وكان اختلف بينهم اختهان إنلافا كثيرا، وأهمها في المعيشاة واللغة ودراجة الثقافة العقلية. وكما ورد في بعض التراث العربي، كان العرب يسـكنون في الجزيرة العربيـة التى يعيش فيها قبائل ذات لهجات مختلفة. وقد قسـم الناسـبون قحطان إلى شـعبين عظيمين

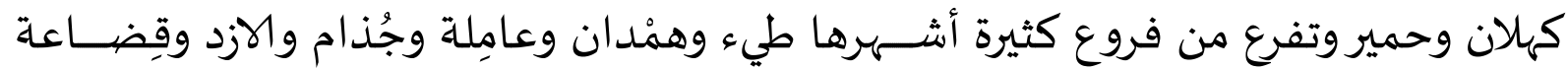

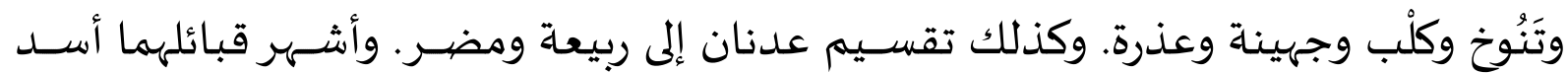

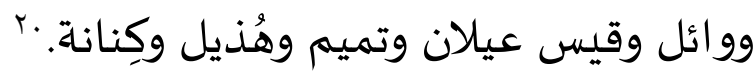

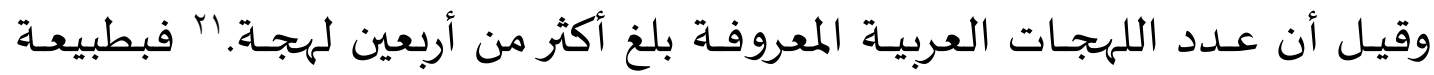

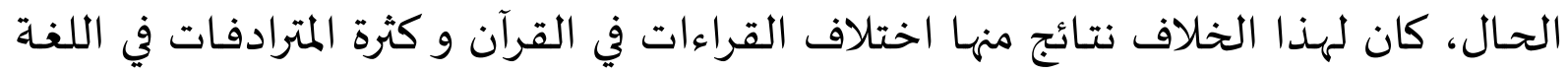

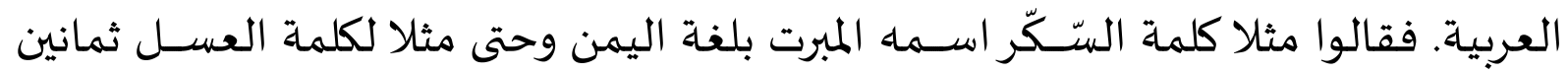

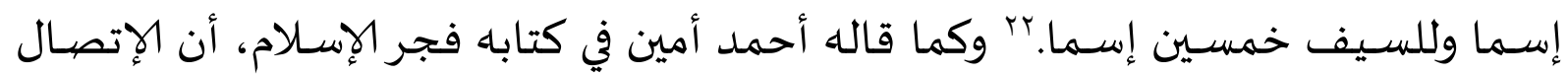

iv

^l عبد الرحمن جلال الدين السيوطى. المزهر في علوم اللغة وأنواعها (بيروت : دار الفكر, مجهول السنة) سم.

19 أمين. فجر الإسلام. ................ 0.

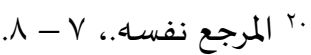

ا شاهين. في تطور. ص ص

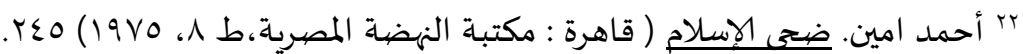


بين العرب وغيرهم كان من طرق عدة. وأهمها التجارة وإنشاد المدن العربية المتاخمة لفارس

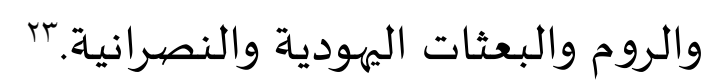

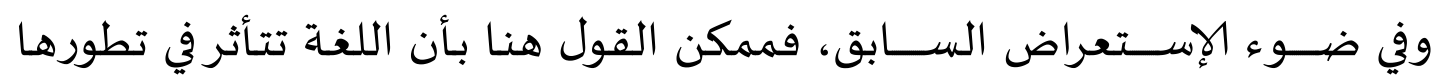

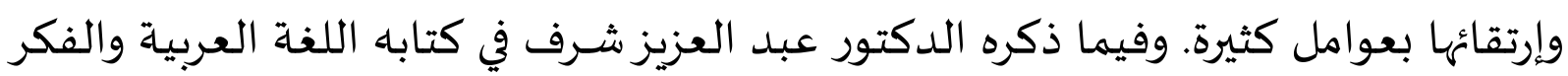

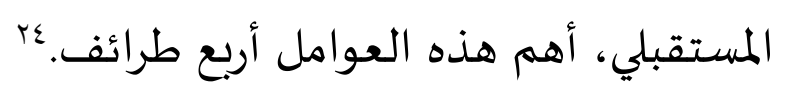

أولها انتقال اللغـة من الســلف إلى الخلف. وثانهيها تأثر اللغنة بلغـة أخرى. وثالثها

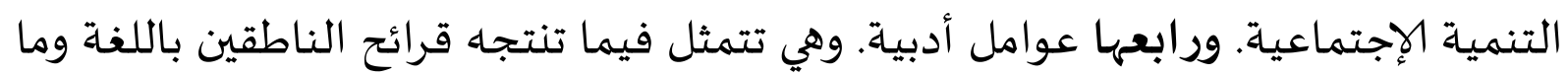

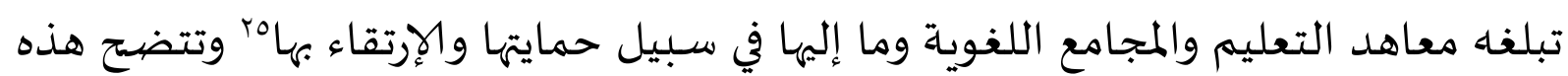

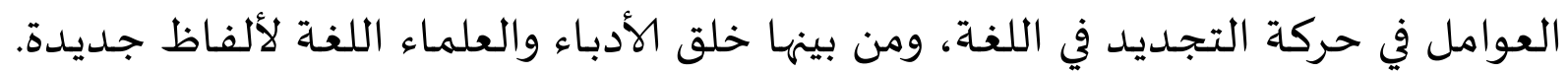
فكثيرا ما يلجئون إلى ذلك للتعبير عن أمور مســتحدثة في الحياة الإجتماعية أو الفكريـة لا لا

يجدون في المفردات اللغة المستعملة، ولا في مفرداتها الدائرة ما يعبر عنها تعبيرا دقيقا.

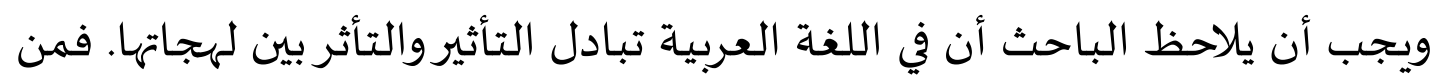

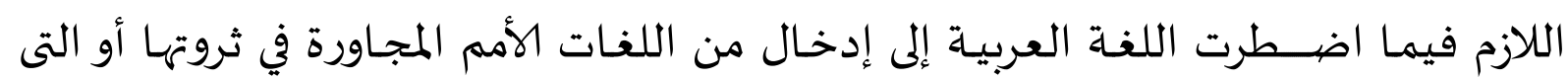

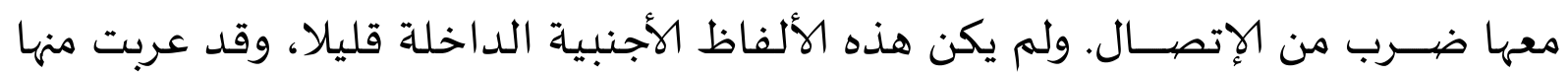

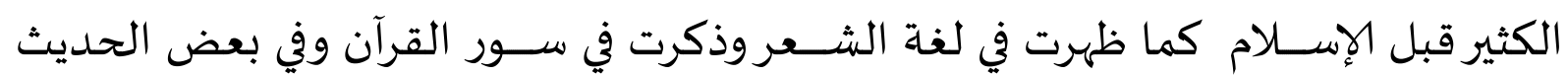
النبوي. الحير فب

وهكذ اســتمرت عملية التأثير والتأثر إلى نهاية عصـــــإلإحتجاج أى في نهاية القرن

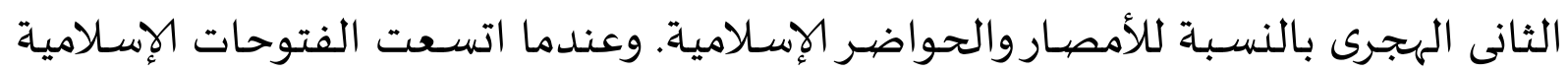
بعد عصر الراشـدين والأموي والعباسي دخل في الإسـلام أمة كثيرة من أهل البلاد المفتوحة.

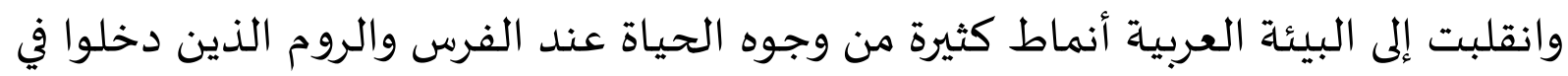

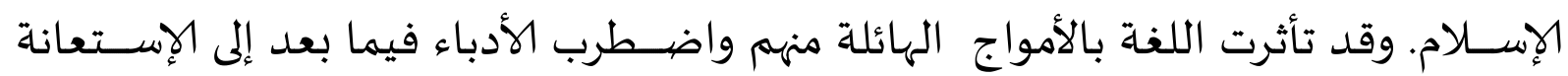

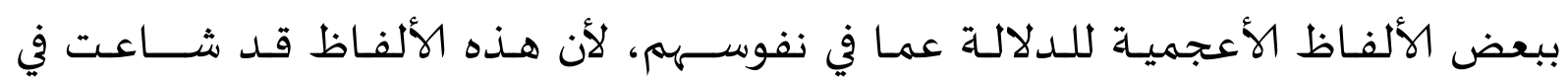

צr أمين. فجر الإسلام.

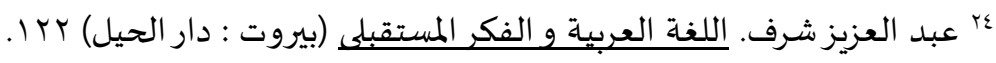
ro وافي. علم اللغة. r r الصالح. دراسات. ................. 
الإســعمال الواقعي .V ولهذا كثرت في لغة الأدب ولغة التخاطب الإجتماعي ما ســي فيما

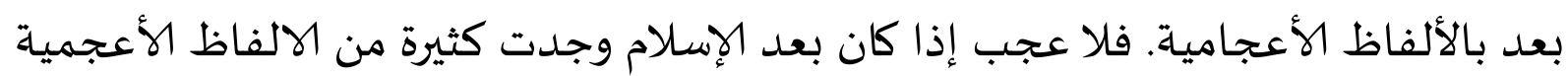
في شكل عربي على ألسنة الأمراء والشعراء وفي البيوت والأسواق.

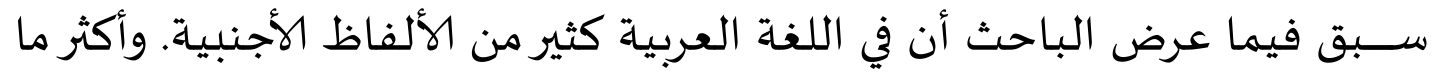

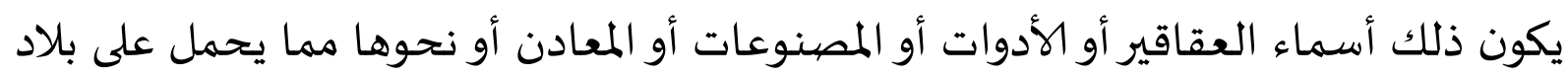

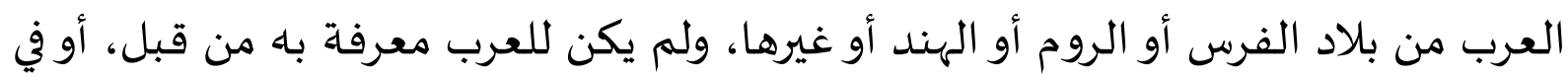

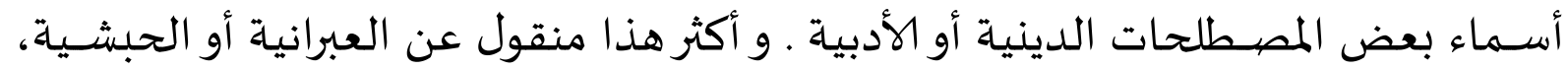

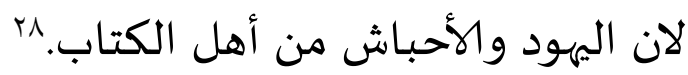
وعلاوة إلى ذلك، فإن أكثر الألفاط التى احتاج العرب إلى إلى تعريها هي ألفاظ الحضيارة

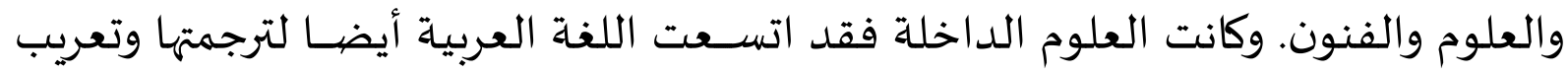

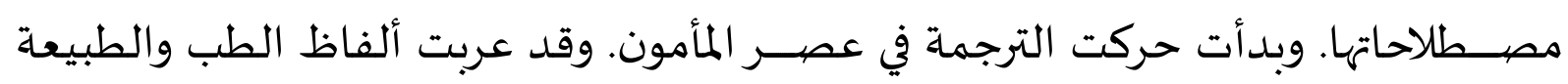

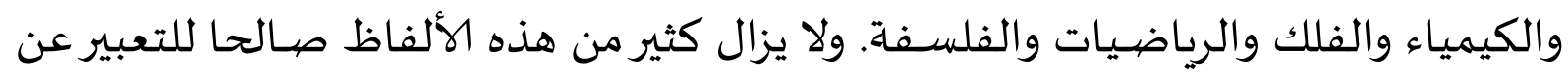
هذه العلوم إلى هذا اليومجاء والفي

وفي جانب آخر هذه تؤدى إلى ما حسثت على اللغة العربية في عصيـور الإنحطاط التى استمرت عدة قرون. فضاعت من اللغة مزية الدقة عرفتها عربية في عصورها السالفة.

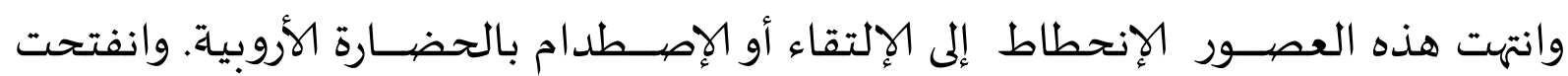

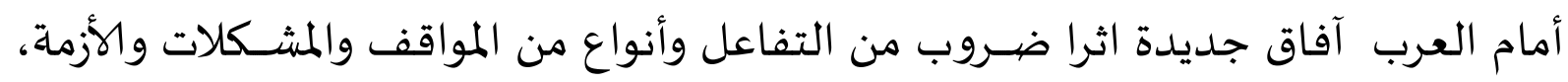
ومنها مشكلة اللغة. وهذه هي التى سيقدمها الباحث في هذا هـا البحث. د. مففوم التعريب

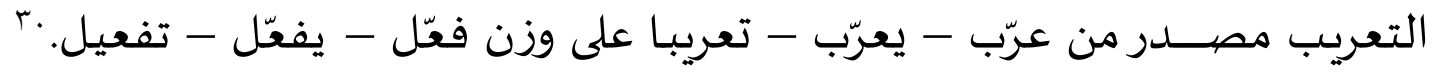

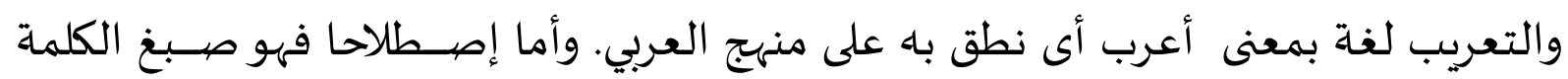

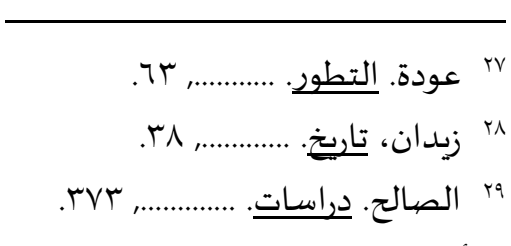

•r أحمد هاشم. مذكرات في النحو والصرف (المدينة المنورة : الجامعة الإسلامية بالمدينة المنورة، ط 1991) عبس. 
بصـبغة عربية عند نقلها بلفظها الأجنبي إلى اللغة العبية.'بّ وقيل أيضـا أن التعريب هو أن

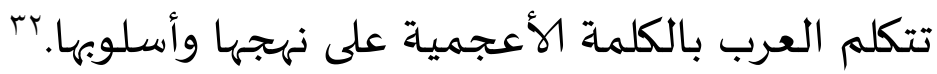

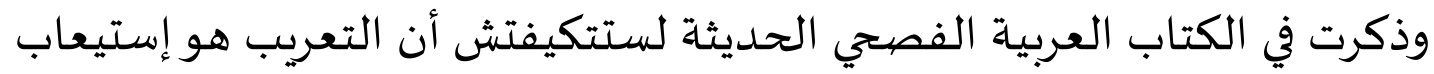

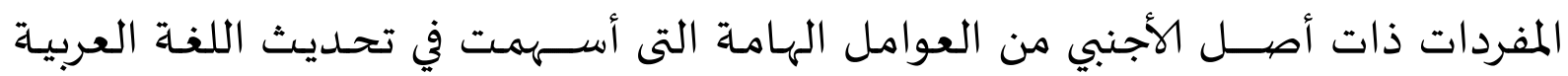

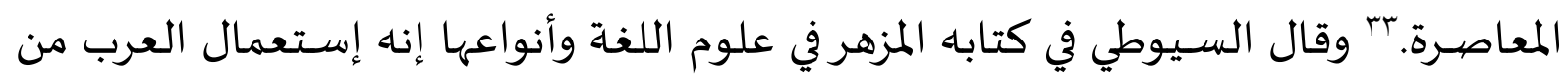

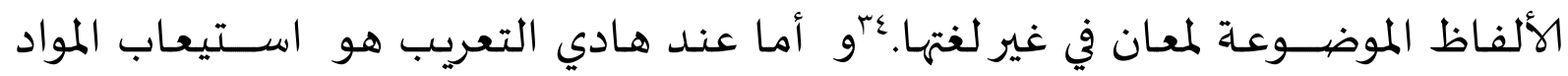

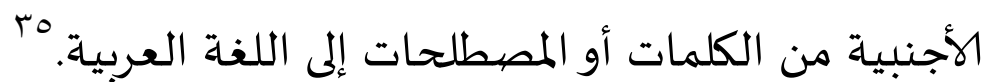

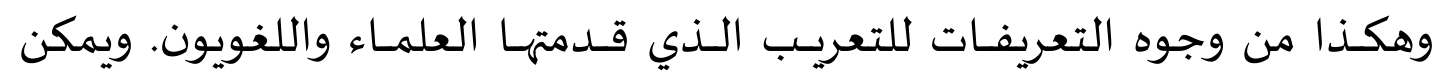
البـاحـث اســتنبـاظ هـذه التعريفـات في أن التعريـب هو إنتقـال اللفظ الأجنبي إلى العربي

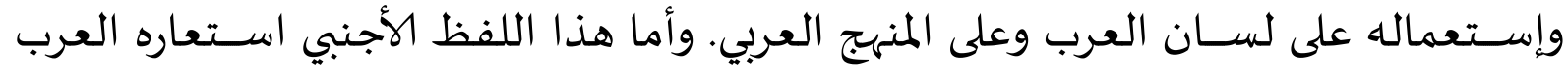
وتنطق باء يسمى بالمعرّب.

و. طريقة التعريب

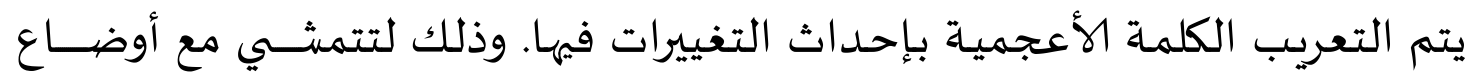

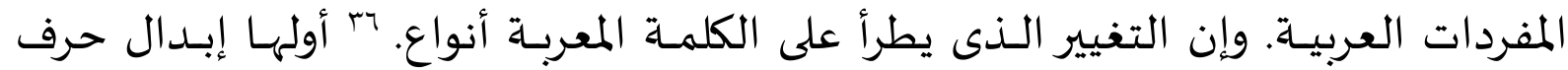

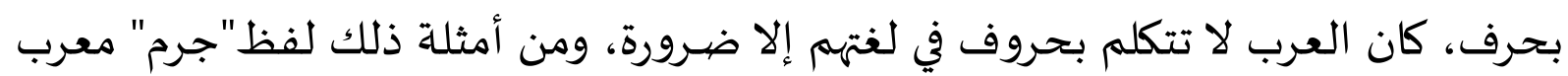

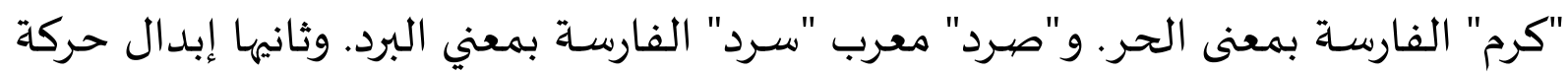

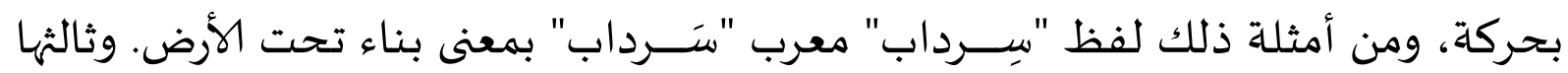

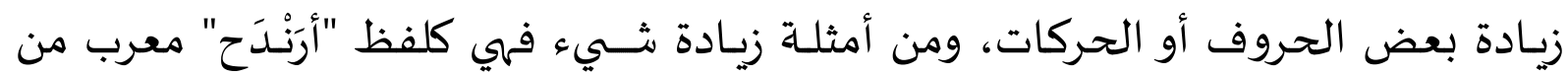

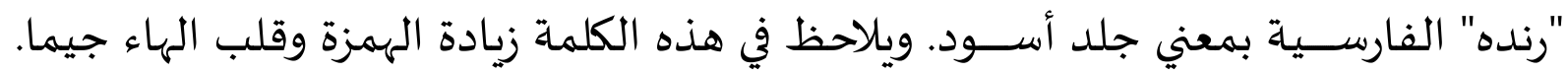

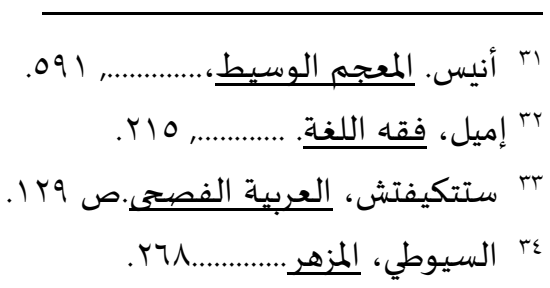

35 Saiful Hadi, Berbagai Ketentuan Baru dalam Ta ' Rib : Pembahasan Seputar Perkembangan Mutakhir dalam Bahasa Arab Seri V. Jurnal Humaniora, XIV(1), 2005, 1. 
ورابعها نقص حرف أو أكثر نحو لفظ "هنْرَ" معرب من "نهره" بمعني باطل. فظهر في هذه الكلمة حذف النون وقلب الهاء جيما في نفس الوقت.

وهكذا أنواع التغيير الطارئ على الكلمة المعربة عند بعض العلماء واللغويين. وأما

الذين لا يشـترطون شـيئا فيعتبرون الكلمة الأجنبية معربة بمجرد نطق العرب بها. "r وهذه كما ذهب إليها ســيبويه التى كانت من الناحية التطبيقية العملية كان أكثر انتشــارا. ورأى سـيبويـا أن التعريب بالقياس إلياه كان مفهوما واسـعا. إنها يضـهم كل المفردات الأجنبية التى استحذمها العرب، وإن بدا بعضها بعيدا عن القوالب الصيرفية الأصيلية في اللغة العربية.؟؟ ومن بينهـا لفظ "خراســـان" التى تمثل الصــيغـة غير العربيـة. وكذلك "إبراهيم، وقنبيط، واطريفل، وآجر، وشطرنج، وغير ذلك.

وظهرت أيضا هذه الأمثلة في المصطلحات الحديثة. فوجد اللفظ تلغراف (telegraph)، وتلفـون (telephone)، وفتـوغراف (thotograph)، وأوتوموبيـل (theatre)، (automobile)، وتيـاترو ) وبلاسـتيك (plastic)، وسـينماتوغراف (cinematograph)، وبروجرام (program)، وكثيرا من نظائرها تكاد تنطق بها كما أنزلت على لسان أهلها.9ج" إضـــافـة إلى ذلك، هنـاك من يرى أن طريقة تأليف المفردات العربية الجـديدة من

$$
\begin{aligned}
& \text { خلال التعريب ثلاثة وهي •؛ : } \\
& \text { () استيعاب المفردات أو المصطلحات }
\end{aligned}
$$

تجري هذه العملية مع تكيف وتغير الألفاظ المعرب من الناحية الصـــوتية أو

$$
\text { الصرفية وفقا لأوضياع الألفاظ العربية على الوقاعد التالية : }
$$

أ. زيـادة يـاء النســبـة للواحق -ist, -an, ic, -al في آخر الكلمــة نحو البـاتولوجي

(phenomenological) و الفينومينولوجي (phatologist)

ب. تغيير صــوت g إلى "ج" في العربيـة نحو كلمـة جيولوجي (geologic) و جغرافيـة (geography)

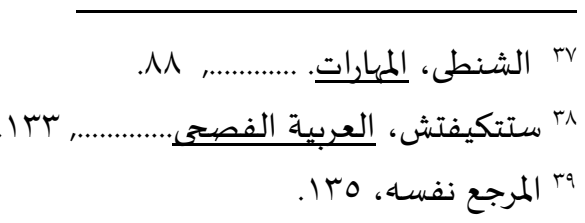

40 M. Afif Amrullah. Analisis Perubahan Morfologis Pembentukan Ta'rib. Tadris : Jurnal Keguruan dan Ilmu Tarbiyah 02 (2) (2017) 87-96 
ج. تغير صـــوت c إلى "س" أو "ك" أو "ق" في العربيـة نحو كلمـة ســينمـا (cinema) و ديموقراطية (democracy)

د. تغيير صــوت إلى "ت" أو "ط" في العربيـة نحو كلمـاة طمـاطم (tomato) و تتـانيوم (titanium)

هـ تغيير صوت ph إلى "ف" في العربية نحو فيلولوجيا (philology) وما إلى ذلك ( ) ( ب الترجمة

تكون هذه الطريقة أثرا على تقدم العلوم الحديثة، ومن أمثلتها :

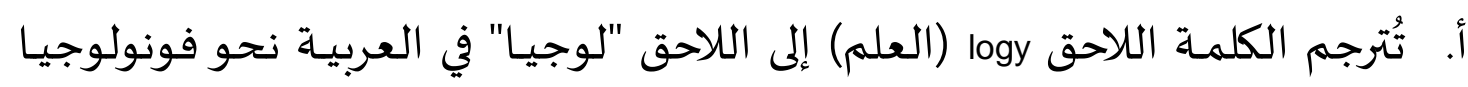
(phonology) ب. تترجم اللواحق iss -ism - إلى اللاحق "يسية " في العربية نحو وجوديّة (extensialism) و سياسيّة (politics)

ج. تترجم كلمة السوابق mono إلى كلمة "أحادي" في أول الكلمةة، نحو أحادي الفونيم (monofonemic)

د. تترجم كلمــة الســـوابق post إلى "بعـــي" أو "خلفي" في أول الكلمـة، نحو خلفي أسناني (post-dental)

هـ تترجم كلمــة الســوابق pre/pra إلى "قبـل" في أول الكلمــة وتخــف لامهـا، نحو قبـأسناني (pradental)

و. تترجم كلمـة الســوابق non إلى "لا" وتبـدأ ب "ال" المعرفـة في أول الكلمـة، نحو اللامقطعي (non-sylabic)

ز. تترجم كلمــة الســـوابق poly إلى "متعـدّد" في أول الكلمــة نحو متعـدد المعـانى (polysemy)

ح. تترجم كلمة السـوابق inter إلى "بين" في أول الكلمة فتخذف نونها متصيلة في أول الكلمة نحو، بينظامي (interdisciplinary) وما إلى ذلك.

ب) تأليف المفردة الجديدة تجري هذه العملية بطريقة الإشـقاق وفقا للأوزان الصـرفية في اللغة العربية، ومن أمثلة ذلك كما يلي : 
أ. الوزن "فُعـال" و "فَعَل" و "فُعِلِ" و "مَفْعول" التى تـل على الأمراض نحو فُصـــام و وَلَب (stomachache) و "بُطِن" أَوْ "مَبْطون (schizophrenia) ب. الوزن "فِعالة" و "فعَّال" الدالتان للمهنـة، نحو صِحافة (journalism) و زهَّار (florist)

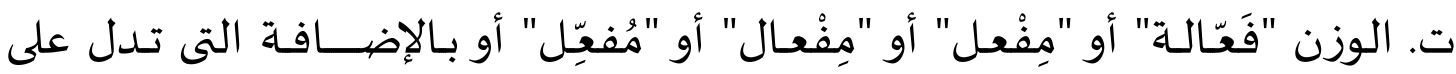

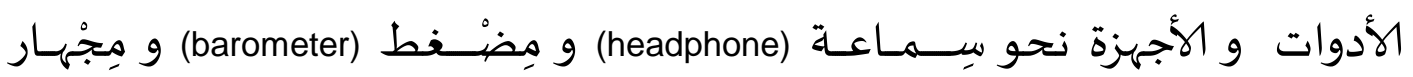

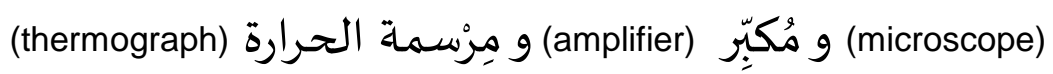

ث. هناك أيضــا ما يســهى بالســتيعاب الصــرفية معرب من الألفاظ الأجنبية نحو

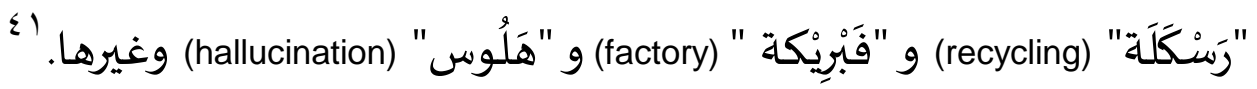

\section{ز. خصيائص التعريب}

تساعد هذه الخصائص أهلها لمعرفة هل اللفظ معرب من الأعجمية أم هو العربية

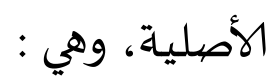

\section{( ) الخروج عن الأوزان العربية}

وقد وافق جميع الكلمات والألفاظ العربية الأصــلية على الأوزان العربية المعينة. وكانت هذه فرق أســابـي تفرقها من الأعجميـة. فلذلك أن هذه من أسـهـل الطرق لمعرفة عجمة الإسم من وجهها الظاهرة أى صيغتها غير عربية.

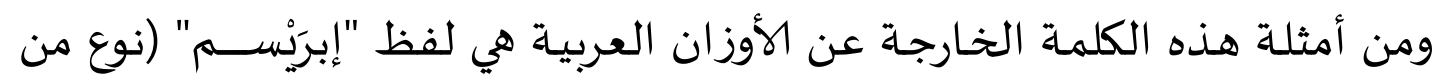
الأقمشـــة الحريريّة)، فإن مثل هذا الوزن مفقود من أبنية الأســماء في اللســـان العربي. بـ وكذلك "خراسان" التى تمثل الصيغة غير العربية (فعالان)و "إبراهيم" (إفعاعيل)، و"قنبيط" (فعليل : بضـهم الفاء وتضـعيف العين المفتوحة)، واطريفل (إفعيلل : بكسـر الهمزة وسـكون الفاء وكسر العين)، وآجر (فاعل : بضهم العين)، وشطرنج (فعلل : بفتح الفاء وسـكون العين وفتح اللام).

\footnotetext{
${ }^{41}$ Abdul Malik, Arabisasi (ta'rib) dalam Bahasa Arab Tinjauan Deskriptif Historis, Adabiyyāt, Vol. 8, No. 2, Desember 2009, 270-273.
}

rV. ك السيوطي، المزهر. 


\section{r}

حكم اللغويون على بعض الألفاظ والكلمات في اللغة العربية بأنها أعجميـة، لأن فيها حرفين يجتمعـان غير موجودة في الكلمـة العربيـة الأصيـليـة، ومنهـا أن يجتمع فيها الصـاد والجيم، نحو الجصّ والصـلجـان، والجيم والقاف، نحو منجنيق، وأن يكون أولها

نون ثم راء، نحو نرجس، وأن يكون آخره زاى بعد دال، نحو مهندز r) خلو الكلمات الرباعية والخماسية من حروف الذلاقة

ويعرف المعرب من الفصيسيح أيضـا بأن يكون رباعيا أو خماسـيا خاليا من حروف موف الذلاقة، مثل "الجوسـق". ويسـتثنى من ذلك كلمة "عسسجدي" أى الذهب إذ نص العلماء على عربيتها.ء؛ وإذا كان اللفظ عربيا، فلا بـد أن يشــتمل على شــيئ من هذه الحروف (البـاء، والراء، والفـاء، واللام، والميم، والنون) نحو "ســفرجيـل" (نوع من الفواكــه)

"وجحمرش" ( المرأة العجوز)

ع) نص أئمة اللغة على عجمتئها (لمراه العجور

وفي هذا الإطار، حكم اللفظ أعجمي أيضـــا إذا كان هنالك النقل عن أئمة اللغة

بأن هذا اللفظ غير عربي. وكان هذا النص الصريح ذكر في كتب اللغة المعتمدة و خاصية في المعاجم. ومن أمثلـة ذلك، فقد نص العلماء على أن الكلمـة "زنـديق"، و"شــطرنج"، و"منجنـيق"، و"بخــت" غير عربيـة. ه؛. وبـالعكس، فقـــ نص العلمـاء على أن اللفظ ح. ضرورة التعريب في اللغدة العربية رغم أنه خاليا من حروف الذلاقة. ومن ضـروريات التعريب في اللغة العربية بالنسـبة لعدم التخرج منـه كما الملاحظة

التناليـة.

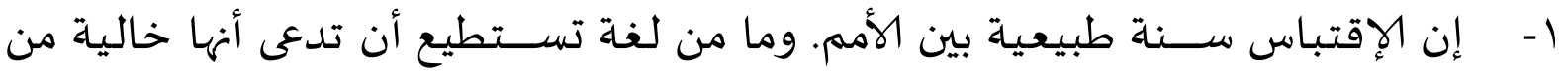
الألفاظ الداخلة.7؛ وبعبارة أخرى إذن، أن اللغة الشـأن الكائن الحى المتطور. فالتطور 
والتغيير من سـنن الله في الكون. ويعتمد التطور اللغوي على الظروف التاريخية وتابعا على التطور الحضاري والعقلي والسياسي.

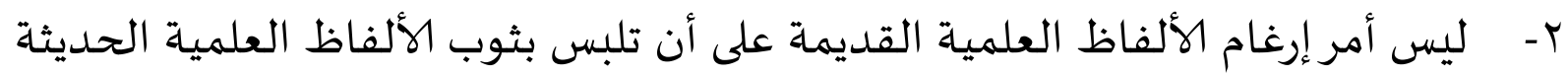

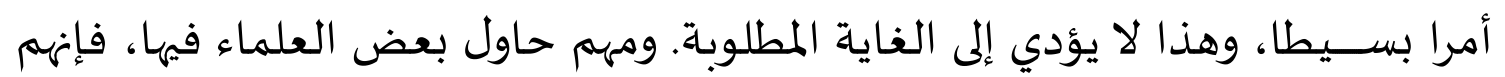

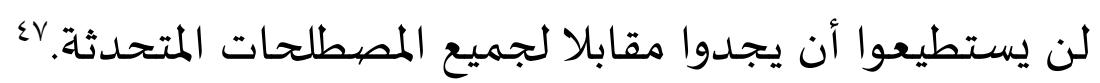
وعلى هذه الملاحظة كانت اللغة العبية تحتاج إلى التعريب، وبخاصة فئ في أسماء وأعيان

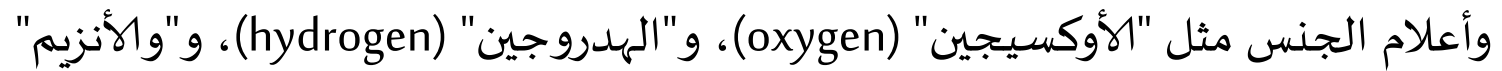

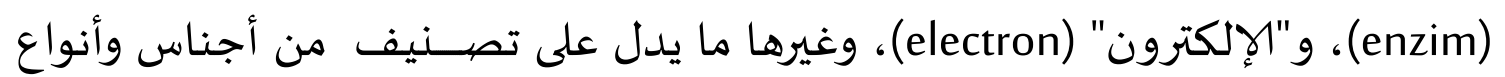

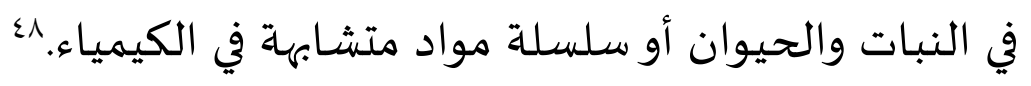

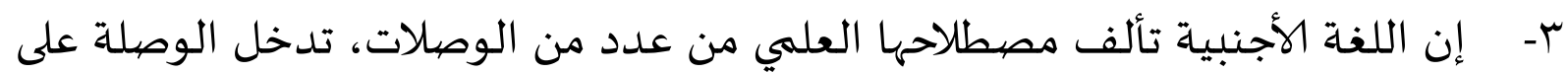

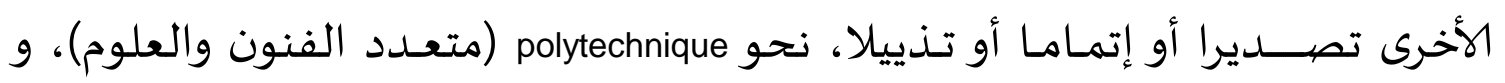
telegraphe

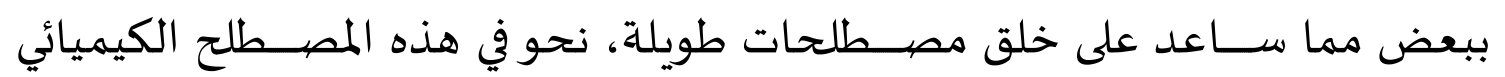
dichlorohydrat metoxy-amino chlorobenyamide

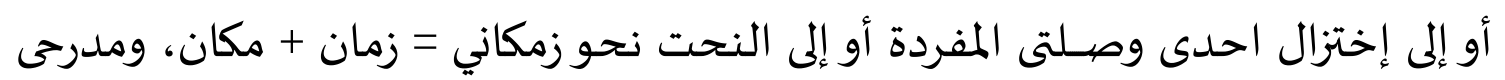
مدة + مورح. وهنـا يبدو أن الإقتبـاس من اللغـة الأجنبيـة أى التعريب أســهل منـالا وأدق دلالة من الته الترجمة أو الإشتقاق أو النحت وما إليها.

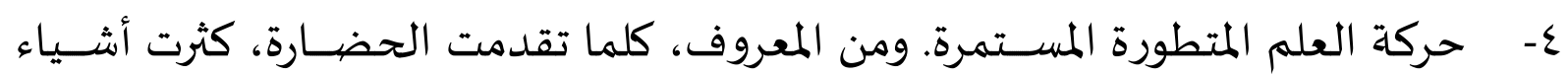

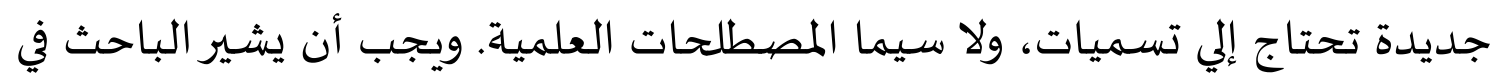

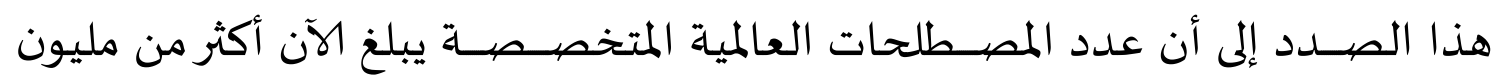


ونصف مليون مفردة. وهذه الحركة لا تنفك، تفرز المصطلحات ما يتراوح بين خمسين ومائة مصطلح جديد يوميا. •

وهـذه التصــريحـات تقرر بوضـــوح أن التعريـب هو من أهم الطرق في وضــع المصطلح العربي العلمي في العصر الحاضر حتى تنمى اللغة العربية بألفاظ العلوم التى تتكاثر يوما بعد يوم. لكن لا يعني هذه كلها تخلو من المشكلات. وإن من أشد ما يعانيـ الباحث هنا، أن التعريب إلي جانب شـارك في تنمية اللغة العربية فإنها يؤدي إلي ظهور المشكلات اللغوية التى تؤثر تطور اللغة العربية في نفس الوقت قليلا فقليلا. ط. مشكلات التعريب في تطور اللغـة العربية فواقع الأمر أن العرب والناطقون بلغتهم لا يزالون يواجهون مشكلات في لغتهم التى سيحاول هذا البحث إنجازها. ويتضح ذلك على البيان التالي : ا. المشكلات في المصطلاح العلمي

عندما انتشــر اللفظ الأجنبي بين الناس ولم تضــع لله المجامع اللغوية اللفظ العربي المقابل لله، فهناك مشـكلة تبدو أحيانا أى السـباق بين الفصـحى والعامية في إيـجاد المعني الجـديد. وبعد إنذاع اللفظ العربي فتكون النتيـجة أن يشـيع اللفظان،

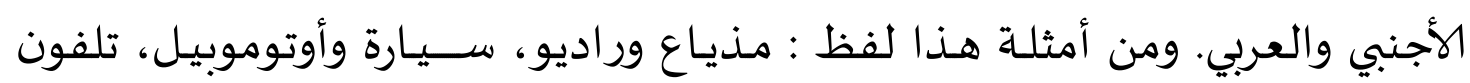
والهاتف، ترام والقطار، وغيرهـا. فلا محسالة إذن، إذا وضــع لفظـا آخر بجـانبـه من العربي الفصيح وضعه ميتا، لأن أكثر الناس لن يستعملوه كلفظ الخيالة والمرياء. وبالتالي، تبدو المشـكلة الأخري أحيانا في كتابة تلك المصـطلحات العلميـة. فيرى بعض العلماء أن أصــوات اللغة العربية التي تطلقها العرب تنقص بعض أصهـوات لأصهـحاب لغات أخرى، اه نحو الباء الثقيلة (p)، والغين الثقيلة (g)، والجيم الثقيلة (j) والفاء الثقيلة (v)، وحروف(x) و (e). وبجـانب ذلك، إن اللغـة العربيـة تخلو من الحروف الصــائتة القصــيرة (vocal)، لذلك بدلت هذه الحروف حركات. به بناء على 
ذلك، فلما كانت الكتابة مجردة من الحركات فلا تتيسر قراءتها الصحيحة المسترسلة

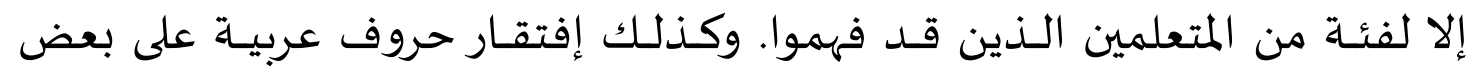

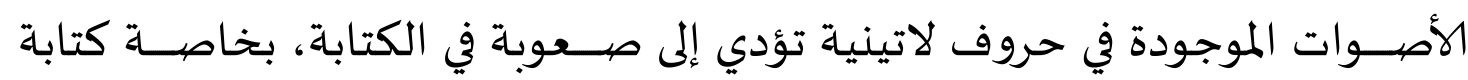
الأعلام الأجنبية أو المصطلحات العلمية الحديثة وغيرها من الألفاظ المعروفية.

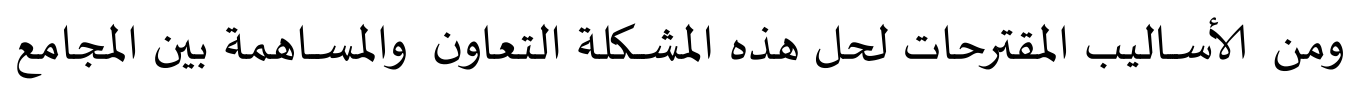

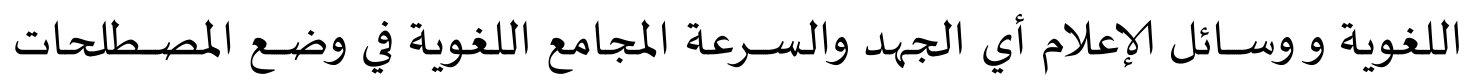

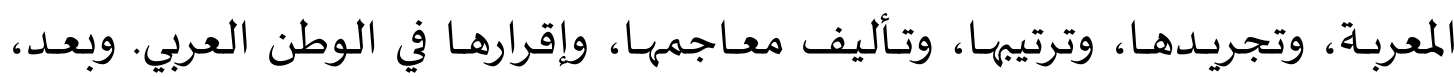

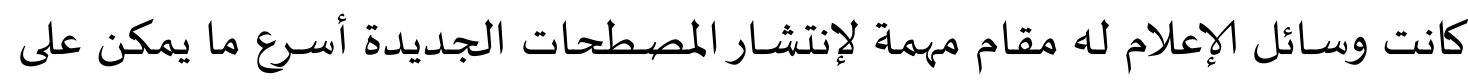

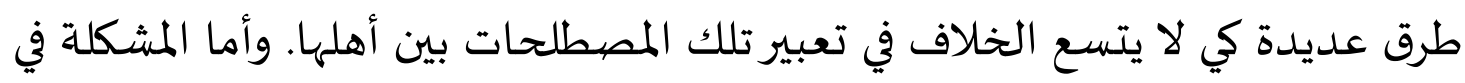
الكتابة، فهناك طريقة تساعد الكاتب العربية في كتابة المصطلحات العلمية الحديثة

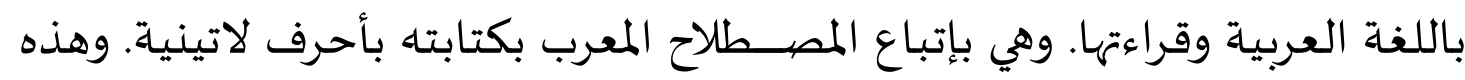

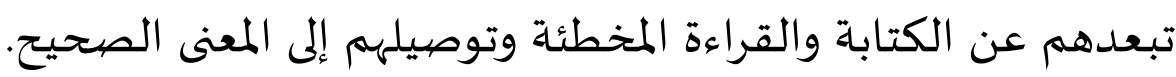

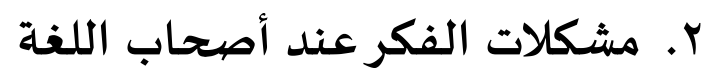

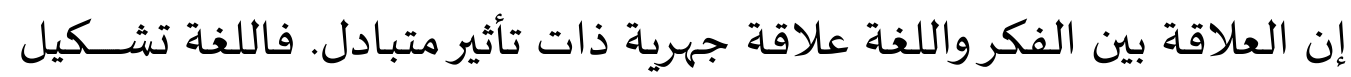

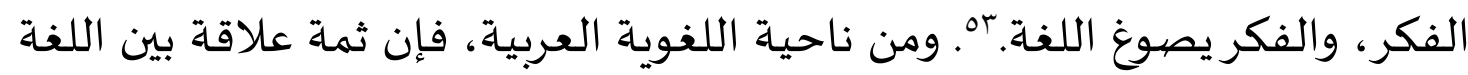
بوصفها نطقا وبين النطق بصفتاه عمل قوانين الفكر تتمثل في اللفظية العربية، وهي

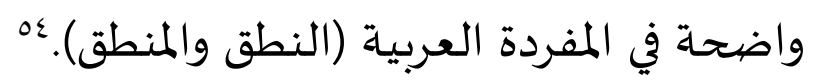

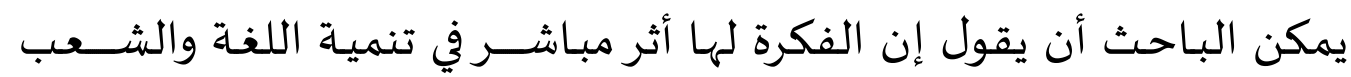

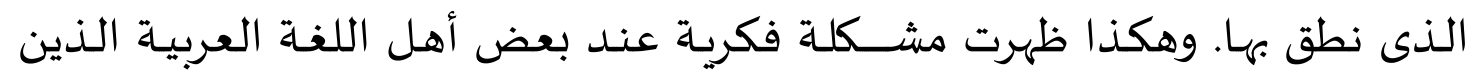

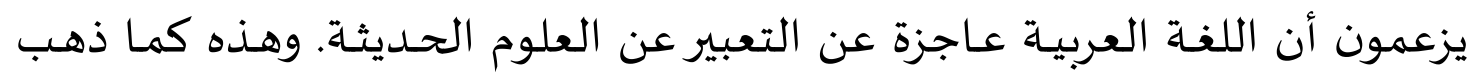

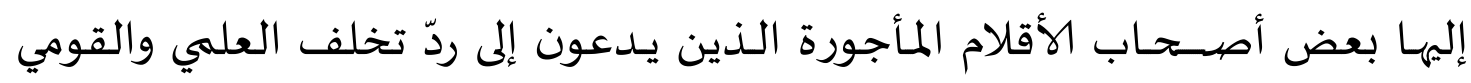

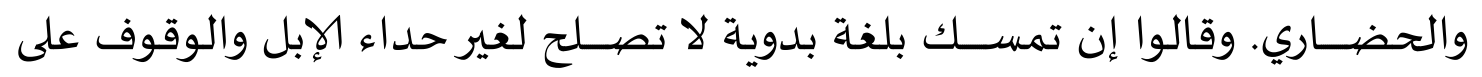

or أحمد صوقي رضوان، التحرير العبلي. (الرياض : عمادة شؤون المكتبات-جامعة الملك سعود) 9.

Al-Af'idah, Volume II, Nomor I Januari 2018 
الطلل. العصر الحديث، فدعاهم إلى العامية أو إلى لغة أجنبية حية إنهائ بديلة.

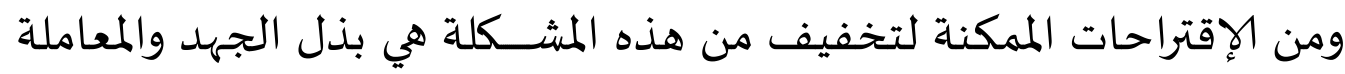

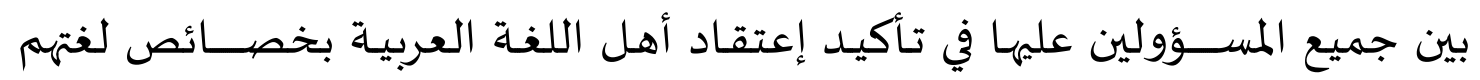

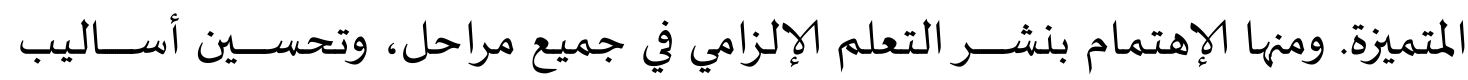

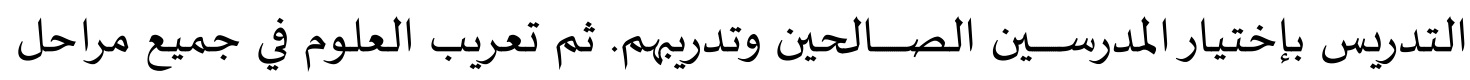

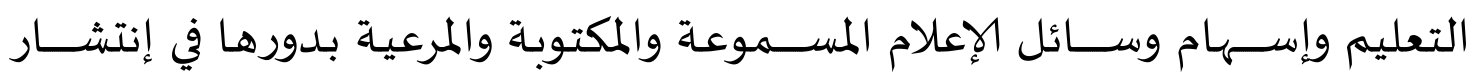
الشؤون اللغوية الجديدة.

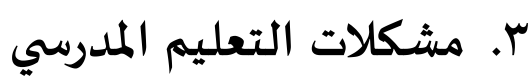

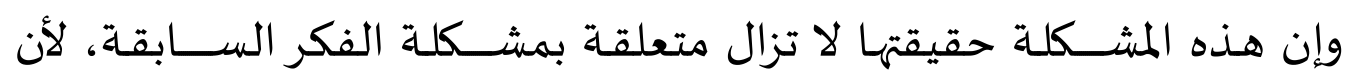

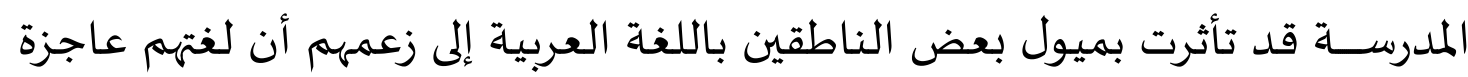

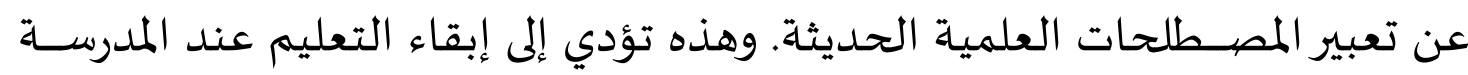
العربية ولا سيما المرحلة العالية منها باللغة الأجنبية.

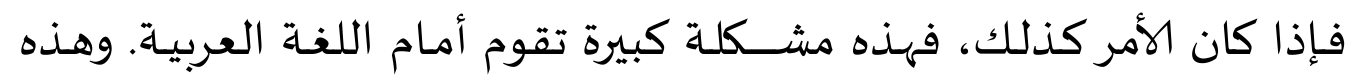

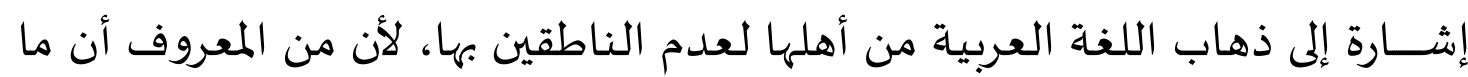

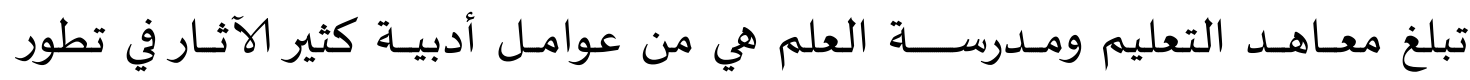

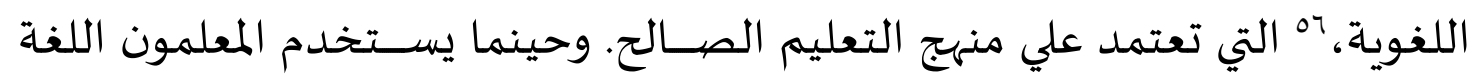

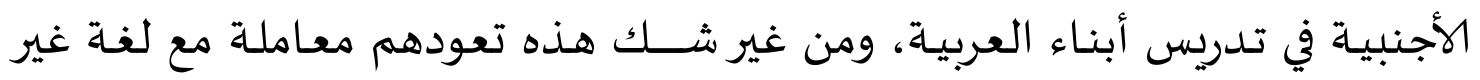

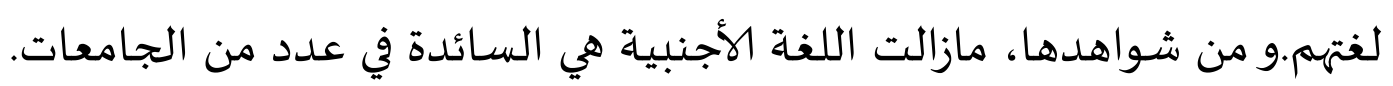
ومن الإقتراحات يقدمها الباحث للتخفيف من هذه المشـكلة فمنها، إسـتخراج

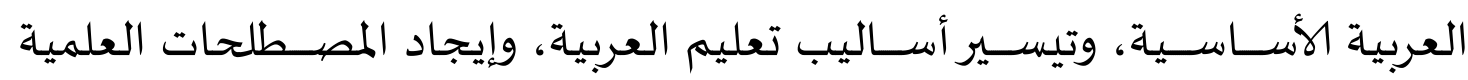

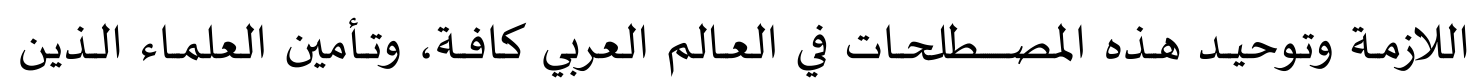

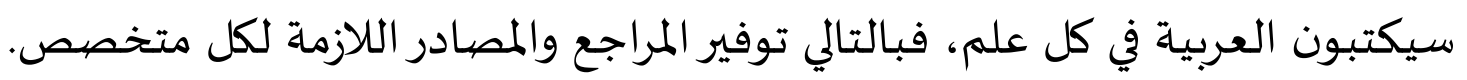




\section{ي. الخلاصة}

التعريب هو صــبخ الكلمـة بصــبغــة عربيـة عنـد نقلها بلفظها الأجنبي إلى اللغـة

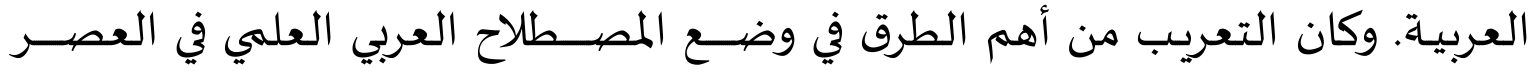

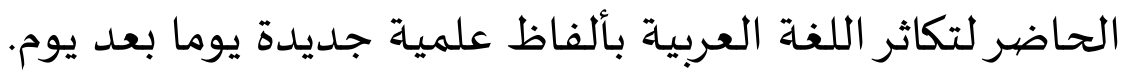

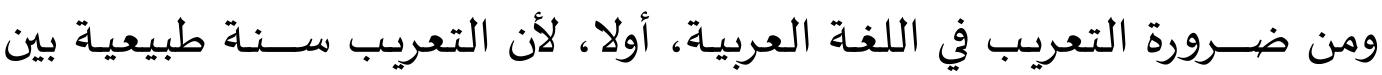

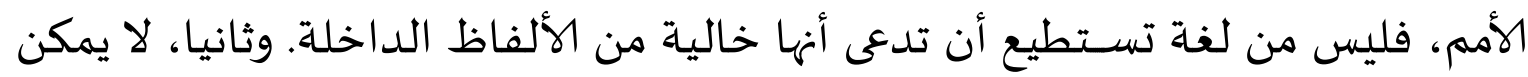

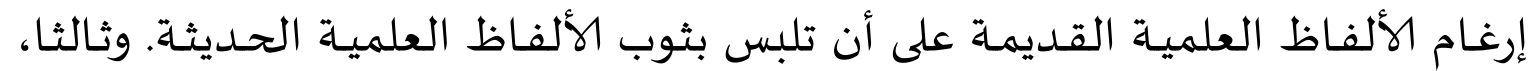

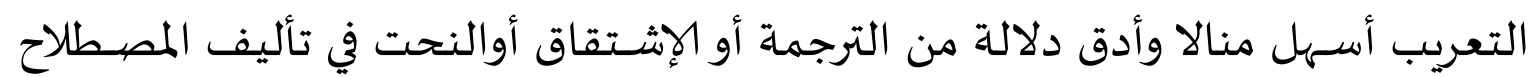

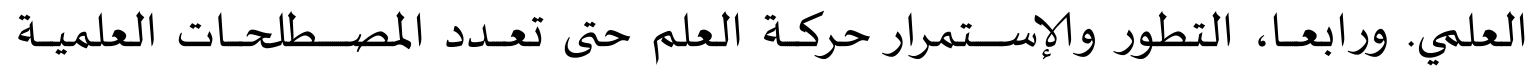
المتخصصية، فالتعريب لا مفر منها. إن من أهم المشـكلات التعريب في اللغة العربية، أولها،مشـكلة المصـــلاح العلهي

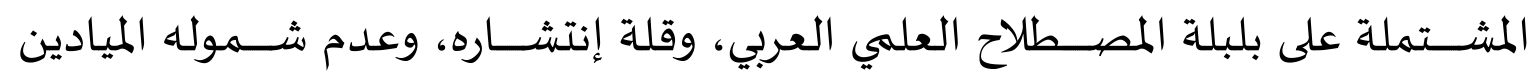

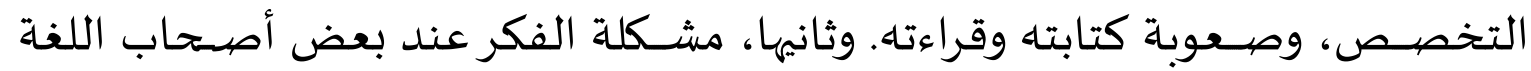

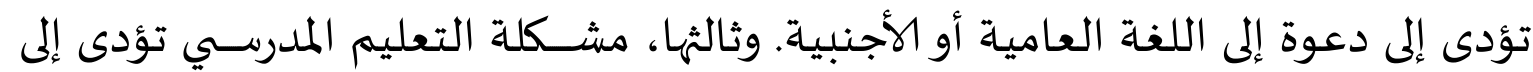
دعوة إلى إبقاء التعليم المواد العلمية باللغة الأجنبية. ومن العلاج الممكنة للتخفيف من هذه المشـكلات فمنها، سـرعة المجامع اللغوية في

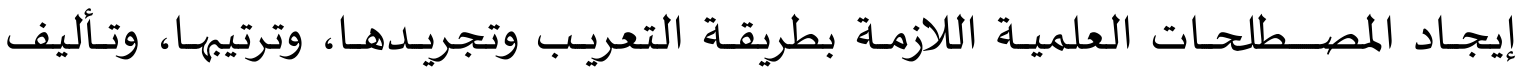
معاجمها، وإقرارها، وتوحيدها في العالم العربي كافة، وإسهام وسـائل الإعلام بدورها في لئه

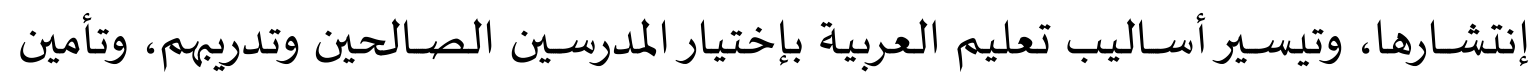
المؤلفين في كل علم، فبالتالي توفير المراجع والمصادر اللازمة لكل متخصص. 


\section{المراجع}

إبراهيم أنيس. المعجم الوسيط ( ج r ، ط Y )مجهول السنة.

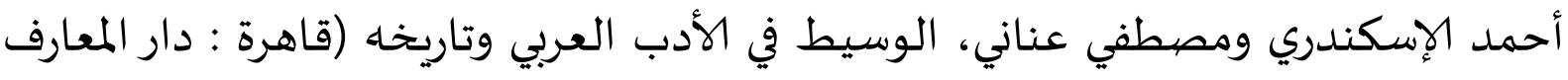
العصر،, ط: 11) مجهول السنة، إلمحمد صالح الشظي. المهارات اللغوية (دار

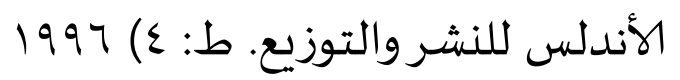
أحمد الهاشمي. جواهر البلاغة في المعاني والبيان والبديع (قاهرة : المكتبة التجارية الكبرى، . 97 ( 97

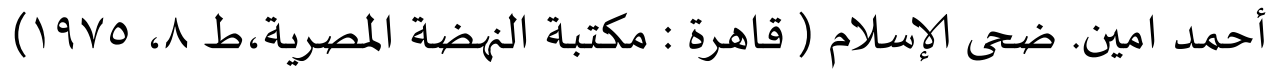

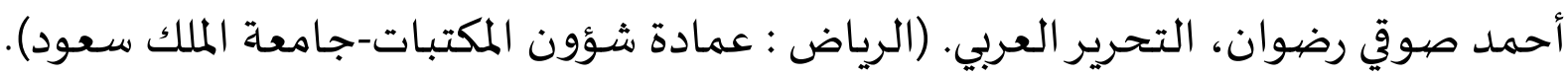

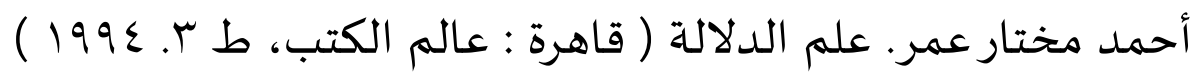
أحمد هاشم. مذكرات في النحو والصرف (المدينة المنورة : الجامعة الإسلامية بالمدينة المنورة، . (1991 b

إميل بديع يعقوب. فقه اللغة العبية وخصائصها ( بيروت : دار العلم الملايين، ط: r ) .61917

حسن إبراهيم حسن. تاريخ الإسلامي اليساسي والديني والثقفي والإجتماعي ( قاهرة : مكتبة

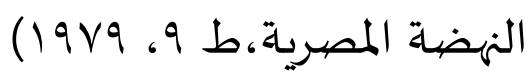

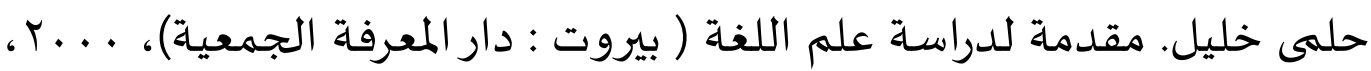

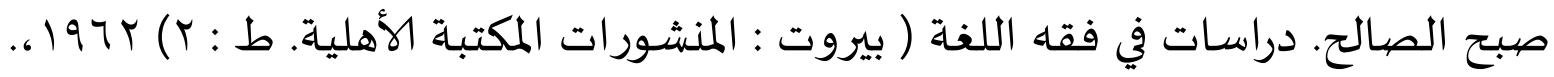

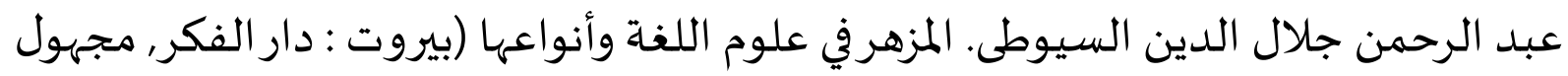

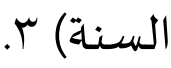

عبد الصبور شاهين. في تطور اللغوي ( قاهرة : مكتبة الشباب، بو 199). عبد العزيزشرف. اللغة العربية و الفكر المستقبلى (بيروت : دار الحيل).

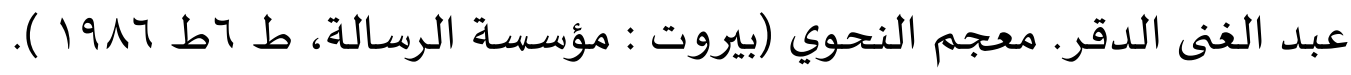

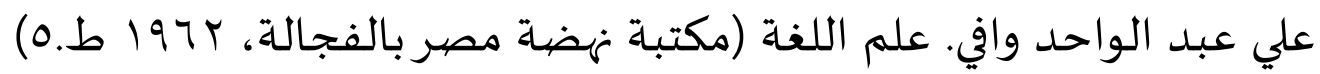




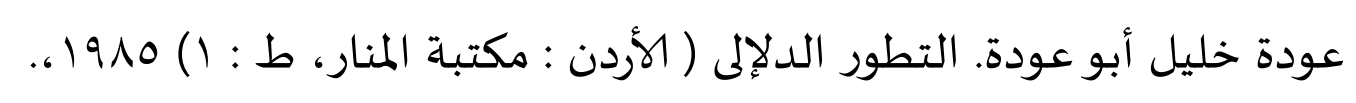

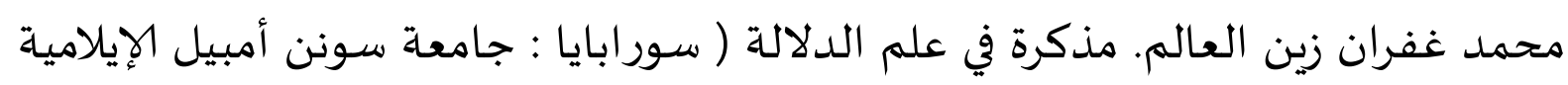

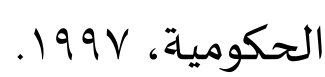

$$
\text { مسعان حميد. علم العروض والقوافي (سورابايا : الإخلاص ) } 1990 .
$$

Abdul Malik, Arabisasi (ta'rib) dalam Bahasa Arab Tinjauan Deskriptif Historis,Jurnal Adabiyyāt, Vol. 8, No. 2, Desember 2009.

M. Afif Amrullah. Analisis Perubahan Morfologis Pembentukan Ta'rib. Tadris : Jurnal Keguruan dan Ilmu Tarbiyah 02 (2) (2017).

Saiful Hadi, Berbagai Ketentuan Baru dalam Ta' Rib : Pembahasan Seputar Perkembangan Mutakhir dalam Bahasa Arab Seri V. Jurnal Humaniora, XIV(1), 2005, 1. 